\title{
On the Cultivation of Customer Loyalty under the E-Commerce
}

\section{Environment}

\author{
Ying Meng ${ }^{1, a}$, Mengfei, Liư ${ }^{2, b}$ \\ ${ }^{1}$ Jiangxi Normal University, Nanchang, Jinagxi, China \\ ${ }^{2}$ Jiangxi Normal University, Nanchang, Jinagxi, China \\ amengyingss@sina.com, \\ bmlamxfg@163.com
}

Keywords: E-commerce; customer loyalty; Internet retailing

\begin{abstract}
With the development of the electronic commerce and information technology, the network commercial activities have become a stream of tide. More and more people are keen on shopping online. Customer loyalty is an important factor that affect customers' future continuous interaction with enterprises. The study analyzes the mechanism which has impact on customer loyalty as well as repurchase intention and also develops a theory framework. Through the analysis of elements that influence customer loyalty, it is concluded that if a company wants to keep gaining profit, it should pay much more attention to these aspects.
\end{abstract}

\section{INTRODUCTION}

Internet has created new business practices and economic models as well as changed people's life greatly. People's shopping behavior extends from the traditional brick and mortar stores to a new form of online stores or electronic stores. As a result, Internet retailing has changed the way of traditional marketing and transaction. According to the relevant research, $80 \%$ of the profits from the enterprise come from $20 \%$ of loyal customers. Therefore, access to loyal customers is a goal that every company wants to achieve.

One view about customer loyalty particularly concerned about the customer's attitude towards certain goods or services, noted that customer loyalty means high repeat purchasing. Brown(1952) classified loyalty into four categories: undivided loyalty, divided loyalty,unstable loyalty, no loyalty[4]. Jacoby \& Chestnut (1978) thought that customer loyalty should be judged from customers' attitude, that is belief, affective and intension[5]. Oliver(1999) put forward his view through a psychological perspective and divided customer loyalty to two parts:action loyalty and attitude loyalty,which further includes cognitive loyalty, affective loyalty and conative loyalty[12].

Another view about customer loyalty is that it is a mental activity. Day(1969) viewed brand loyalty as consisting of repeated purchases promoted by a strong internal disposition[2]. Catherine(2012) pointed out that customer loyalty is a belief that when customers want to buy goods what he had used or that may be needed in the future, he takes your company into the first consideration[1].

Reichheld and Schefter(2000) found in the study that the effect of customer loyalty in the traditional business of "first loss after a profit" is more obvious than online[11]. In the early stage, to build relationships with customers, enterprises engaging in E-commerce which plan to obtain a new customer pay much higher than the traditional business enterprises. 
Survey has showed the recent number of Chinese online customers(see from figure 1), the growing speed of which has surprised many people as well as increased the attention on e-customers and their loyalty.

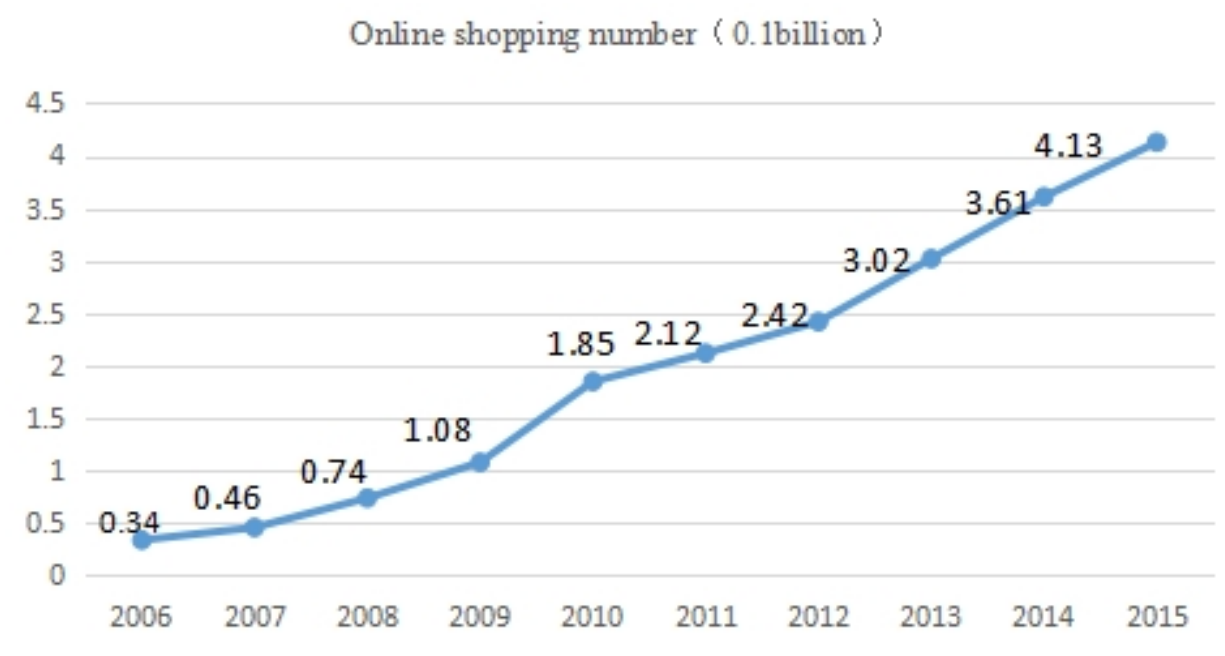

Figure 1. Online shopping number in recent 10 years in China

\section{CUSTOMER LOYALTY}

According to former study, Customer Loyalty can be enormously influenced by customer satisfaction and switching costs. And shopping experience, website design as well as product quality and service result in customer satisfaction(See figure 2).

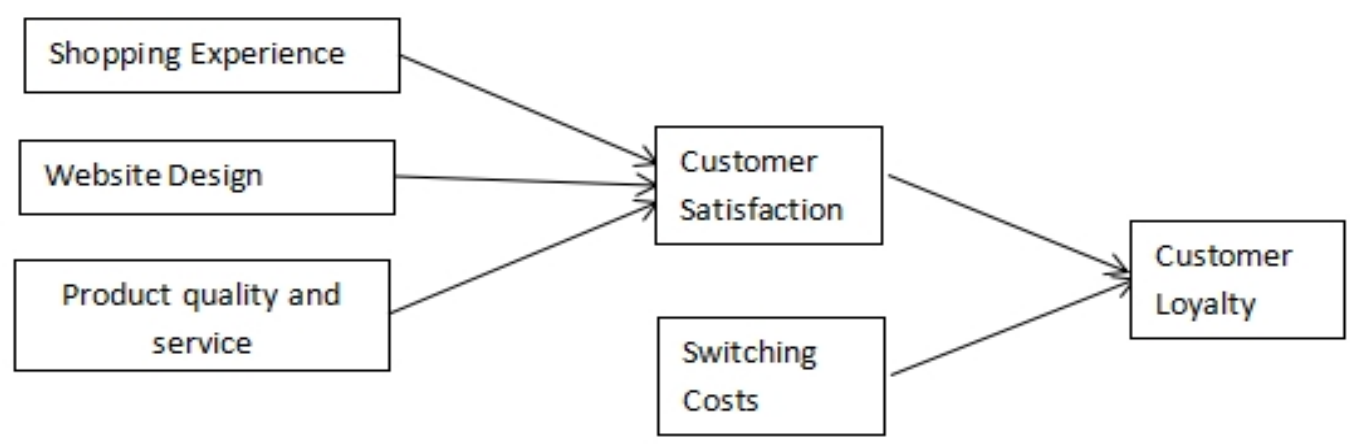

Figure 2. A framework for Customer Loyalty

\section{Customer satisfaction}

Marketing scholars' view on customer satisfaction concept is basically the same. Kotler (2006) said: satisfaction is a person's feeling of pleasure or disappointment resulting from comparing a product's perceived performance(or outcome) in relation to his or her expectation[9]. When people have a higher customer satisfaction, they will buy more of the product. Customer loyalty will increase with customer satisfaction. And customer satisfaction is one of the most important factors driving customer loyalty. So what will affect customer satisfaction?

The shopping experience of customer

Customer experience refers to the customers' experience of knowledge and information to the product or service. Francis Buttle (2008) found that the affection and cognition of customer experience could be affected by a company's employees, products, service and outcome[3]. In addition, Olson (2010) noted that in order to both direct and indirect drive customer and increase 
sales volume and profit, the development and behavior analysis of customer experience could be examined by affective experience, consumer behavior, and consumer environment[9]. If a customer is more satisfied than he expected after the first shopping experience, there is no doubt that he will return.

Website design

Website design contains two parts: content and security.

Content determines whether to buy it or not. If the site design is reasonable, and eye-catching, it will attract more and keep the potential consumer stay longer. First impression is crucial both for traditional business and E-commerce enterprises. A site of rich content, rational layout and clear theme is easier to attract customers than a complicated interface site. When the pursuit of fast-paced life make people increasingly impatient, it would be better to shorten their time on surfing.

Ratnasingham(2013) showed that the fear of credit card fraud is one of the main reasons that hinder customers' activity of online shopping[10]. Customer satisfaction in E-commerce businesses comes from security provided by enterprises, including trustworthy information content, reliable product and secure payment process. Therefore, the development of trust in these ways are concentrated to the network. An anonymous survey of online consumer found that the main driving force of their shopping at a particular site is not about the price, but their sense of trust.

3.Product quality and service

Customer satisfaction is basically depend on its quality. A product of high quality can lead to repeated purchasing. High quality products, including brand, quality, prices and personality, are what people pursue for in the Internet age.

\section{Switching costs}

Switching costs are the price customer paid to re-select a product or service. Klemperer (1995) pointed that many customers in the market would face the issue of switching costs, at least three types of which:transaction costs, learning costs, artificial or contractual costs[7]. Johns et al.(2000) divided the switching cost into six dimensions, namely: loss performance costs, uncertainty costs, pre-switching search and evaluation costs, post-switching behavioral and cognitive costs, setting up costs and sunk costs[6]. Switching costs include various aspects that it sometimes will stop customers to alter to another enterprises.

So the Increasing the switching cost is helpful to establish and maintain customer loyalty. The development of the network era of information reduces the search costs, it also corresponding lower switching costs. Customers can simply tap the mouse and easily switch from one company to another company. While searching costs for customers have reduced, but the E-commerce business can use a special way to increase customer switching costs.

\section{CONCLUSIONS}

Under the E-commerce environment, there is a growing competence. Studying on the E-loyalty plays an important role in enterprise development. So understanding and nurturing customer loyalty is a core issue for business. Information transfer and resource sharing break the boundaries of the original era of the market. Companies spend a relatively low cost can build their own retail business over the Internet. E-commerce will undoubtedly bring new competitive advantage to help companies effectively develop the market. E-commerce break down geographical separation, shortening the time of flowing goods and reducing logistics costs. This is not only a technical change for the traditional retail industry, but also a deep development of marketing strategy.

This paper focuses on the factors affecting customer loyalty under E-commerce environment, and analyzes how can they have impact on it. Consuming experience, website as well as product 
quality and service can have a significant effect on customer satisfaction, and customer satisfaction, together with switching costs, have a closing relation with customer loyalty. Thus in order to foster customer loyalty, enterprises must start from the above factors, focusing on web-design, brand building, increasing switch costs and so on.

There must be more factors that are related to E-loyalty which are not discussed in this paper,and that is also the limit of this paper,hope further study will consider much more elements.

\section{REFERENCES}

[1].Catherine A. Customer Store Loyalty on Supermarkets in Kenya[M]. LAP LAMBERT Academic Publishing, 2012.

[2].Day G S. A Two-Dimensional Concept of Brand Loyalty[M]// Mathematical Models in Marketing. Springer Berlin Heidelberg, 1976:89-89.

[3].Francis Buttle. Customer relationship management [J].Journal of services marketing,2008.

[4].G.H. Brown. Brand loyalty - Fact or fiction?[J]. Advertising age, 1952:53-55.

[5].Jacoby J, Chestnut R W. Brand Loyalty Measurement and Management[J]. Journal of Marketing Research, 1978, 15(4).

[6].Jones M A, Mothersbaugh D L, Beatty S E. Switching barriers and repurchase intentions in services[J]. Journal of Retailing, 2000, 76(00):págs. 259-274.

[7].Klemperer P. Competition when Consumers have Switching Costs: An Overview with Applications to Industrial Organization, Macroeconomics, and International Trade[J]. Review of Economic Studies, 1995, 62(4):515-39.

[8].Kotler dan Keller, Kevin Lane,"Marketing Management, 12th Edition", Pearson-Prentice Hall, New Jersey,2006.

[9].Olson J, Zaltman G. Thinking Deeper about Customer Experience[M]. 2010.

[10].Ratnasingham P. Internet - based EDI trust and security[J]. Information Management \& Computer Security, 2013, 6(1):33-39.

[11].Reichheld F F, Schefter P. E-Loyalty: Your Secret Weapon on the Web[J]. Harvard Business Review, 2000, 78(4).

[12].Richard Oliver.Whence Consumer Loyalty[J].Journal of Marketing,1999. 